\title{
Penguatan Konsep Dasar Matematika Pada Kelompok Kerja Guru Gugus XIV Kecamatan Bacukiki Barat Kota Parepare
}

\author{
Zaid Zainal \\ Program Studi PGSD, Fakultas Ilmu Pendidikan, Universitas Negeri Makassar \\ zainal.zaid@gmail.com
}

\begin{abstract}
ABSTRAK
Kurikulum 2013 mengharuskan pengajaran materi pelajaran pada suatu tingkatan secara terpadu, yang dikenal dengan istilah tematik. Artinya pada satu tema boleh mengaitkan beberapa mata pelajaran di dalamnya. Setelah dilakukan evaluasi pelaksanaannya, maka kurikulum 2013 edisi revisi memberikan perkecualian pengajaran matematika harus diajarkan tersendiri. Permaslahan utama yang dihadapi oleh guru khususnya dalam pengajaran matematika adalah; kurang menguasai konsep dasar matematika, masih terdapat berbagai materi yang tidak tahu diajarkan dan sering terdapat soal-soal matematika yang sulit diselesaikan. Kegiatan pengabdian ini bertujuan untuk membantu guru kelas atas pada gugus XIV kecamatan Bacukiki Barat Kota Parepare (mitra) dalam memahami konsep dasar matematika, membantu menyelesaikan soal-soal yang dianggap sulit serta materi matematika yang sulit diajarkan.Pelaksanaan kegiatan dalam bentuk workshop penguatan materi matematika pada kelompok guru mitra..Metode pengajaran interaktif, pengerjaan soal secara bersama serta pemberian tugas mandiri terbukti dapat meningkatkan pengetahuan dan pemahaman konsep dasar matematika bagi guru mitra.
\end{abstract}

\section{Kata kunci: konsep dasar matematika}

\section{PENDAHULUAN}

Dalam rangka upaya peningkatan mutu pembelajaran serta kemampuan profesionalisme tenaga pendidik khususnya pada tingkat SD/MI maka dibentuk sebuah wadah dengan istilah Kelompok Kerja Guru (KKG). Pembentukan wadah ini merujuk pada keputusan Dirjen Dikdasmen nomor 070/C/KEP/I/93 tanggal 7 April 1993 tentang pedoman pelaksanaan system pembinaan professional guru melalui sekolah di Sekolah Dasar.

Hasil Ujian Kompetensi Guru (UKG) 2015 menunjukkan rendahnya perolehan nilai guru yang ada di Parepare. Dari 948 orang guru SD di Parepare yang ikut tes 783 orang atau 82,6 \% memperoleh nilai dibawah standard yaitu 55,5. Dan nilai rata-rata hasil UKG guru SD di Parepare adalah 44,80. Dari hasil analisis dan wawancara terhadap beberapa guru umumnya mengalami kesulitan pada peguasaan materi utamanya materi pelajaran Matematika.

Khusus permasalahan penguasaan materi pelajaran, sangat terkait dengan kemampuan personal seorang guru. Kemapuan personal yang dimaksud adalah penguasaan materi atau mata pelajaran yang akan diajarkan di kelas. Pada sekolah dasar terdapat dua kategori guru, yaitu guru kelas dan guru mata pelajaran (agama dan penjaskes). Guru kelas terbagi lagi menjadi guru kelas bawah (I,II, dan III) dan guru kelas atas (IV, V, dan VI). Seorang guru kelas dituntut harus menguasai semua mata pelajaran (kecuali penjas dan agama) pada kelas yang menjadi tanggung jawabnya. Kurikulum 2013 mengharuskan pengajaran materi pelajaran pada suatu tingkatan secara terpadu, yang dikenal dengan istilah tematik. Artinya pada satu tema boleh mengaitkan beberapa mata pelajaran di dalamnya. Setelah dilakukan evaluasi pelaksanaannya, maka kurikulum 2013 edisi revisi memberikan perkecualian pengajaran matematika harus diajarkan tersendiri.

Adapun tujuan pelaksanaan kegiatan ini adalah; (1) meningkatkan pengetahuan /pemahaman guru-guru kelas atas pada gugus XIV Kecamatan Bacukiki Kota Parepare tentang konsep dasar Matematika, (2) meningkatkan pengetahuan/pemahaman guruguru kelas atas pada gugus XIV Kecamatan Bacukiki Kota Parepare tentang materi matematika di SD yang dianggap sulit diajarkan, (3) membantu guru-guru kelas atas pada gugus XIV Kecamatan Bacukiki Kota Parepare dalam menyelesaikan soal-soal matematika yang dianggap sulit dikerjakan. 


\section{METODE KEGIATAN}

Untuk menjawab permasalahan yang telah diuraikan, maka pengabdian kepada masyarakat ini menawarkan solusi berupa "Workshop Pengembangan karir guru berkelanjutan pada kelompok kerja guru (KKG) gugus XIV Bacukiki Barat Kota Parepare".

Pelaksanaan kegiatan diawali dengan pertemuan dengan ketua KKG Bapak Drs. Abd. Wahab di SD 12 parepare pada tanggal 17 April 2017 sehingga didapatkan gambaran tentang keberadaan dan banyaknya anggota KKG gugus XIV Kecamatan Bacukiki Parepare, kemudian disepakati pertemuan selanjutnya bersama dengan ketua penaggung jawab bidang studi guna membicarakan jadwal pembagian kuesioner terhadap semua guru dalam lingkup KKG gugus XIV pada tanggal 20 April 2017 di sekretariat KKG gugus XIV di SD Negeri 12 Parepare,

Selanjutnya pemberian kuesioner kepada semua anggota KKG, dimaksudkan untuk mengetahui mata pelajaran/materi apa yang sangat diperlukan oleh guru dalam rangka penguatan pembelajaran di sekolah masingmasing. Berdasarkan kesepakatan sebelumnya maka pembagian kuesioner dilaksanakan pada tanggal 22 April 2017 yang dikuti oleh semua anggota KKG Gugus XIV di SD Negeri 35 Parepare. Berdasarkan hasil angket yang diberikan diperoleh gambaran bahwa ada Mata pelajaran yang sangat perlu untuk diberi pengutan kepada guru-guru pada kelompok KKG gugus XIV, yaitu Matematika, TIK dan Pembuatan karya ilmiah.

Setelah diperoleh 25 orang guru yang akan mengikuti workshop, selajutnya dilaksanakan FGD (Forum Group Discussion) pada tanggal 25 April 2017 guna memilah dan memilih materi yang dianggap sukar dan sulit untuk diajarkan pada proses Belajar Mengajar di kelas. Adapun materi Matematika yang disepakati untuk dijadikan materi workshop adalah: Bilangan, Bangun datar, bangun ruang, statistika dan pengukuran.

Waktu pelaksanaan kegiatan pembelajaran berjumlah 42 jam pelajaran, dengan rincian: Ceramah $/$ tatap muka $=6 \mathrm{kali}$ pertemuan(@4 jam pelajaran)dan pemberian tugas mandiri 18 jam pelajaran. Pelaksanaan kegiatan dilaksanakn pada awal tahun pelajaran dan dilaksanakan pada waktu selesai jam proses belajar mengajar pagi hari (13.00 15.30).

Metode yang diterapkan dalam workshop berupa pembelajaran di kelas (ceramah, tanya jawab, mengerjakan soal) dan pemberian tugas mandiri., dengan proporsi masing-masing $60 \%$ dan $40 \%$. Dalam proses pembelajaran, sangat ditekankan tentang penguasaan konsep dasar serta berbagai kesalahan-kesalahan yang sering dilakukan olehguru di lapangan sehingga pemahaman siswa terhadap materi yang disampaikan sangat kurang. Dengan demikian selama berlangsungnya proses pembelajaran dalam workshop ini berjalan secara interaktif. Selanjutnya pengerjaan soal-soal dari materi yang diberikan, diawali dengan soal yang sangat mudah sampai dengan soal yang mempunyai tingkat kesukaran yang tinggi. Pengerjaan soal-soal yang sukar dengan metode cepat dari instruktur merupakan hal yang sering dinanti-nantikan oleh para peserta workshop.

\section{HASIL DAN PEMBAHASAN}

Indikator dari keberhasilan ini dapat dilihat dari hasil evaluasi proses dan hasil evaluasi tugas mandiri yang dicapai oleh peserta. Evaluasi proses dilakukan dengan memberikan angket/kuesioner kepada peserta yang berisi tentang pernyataan seputar pelaksanaan workshop dan evaluasi hasil dilakukan dengan menilai hasil tugas mandiri dari para peserta selama kegiatan dilaksanakan.. Perhatikan table 1.

Indikator dari keberhasilan ini dapat dilihat dari hasil evaluasi proses dan hasil evaluasi tugas mandiri yang dicapai oleh peserta. Evaluasi proses dilakukan dengan memberikan angket/kuesioner kepada peserta yang berisi tentang pernyataan seputar pelaksanaan workshop dan evaluasi hasil dilakukan dengan menilai hasil tugas mandiri dari para peserta selama kegiatan dilaksanakan. Perhatikan table 1:

Pada tabel 1 menunjukkan bahwa umumnya peserta mengangap baik kegiatan ini, baik dari segi materi, fasilitas, instruktur alokasi awaktu dan kesuaian materi dengan materi di kelas yang dia ajar. Data di atas juga menunjukkan bahwa tidak ada peserta yang memberikan penilaian buruk atau buruk sekali terhadap pelaksanan keiatan ini. Selanjutnya untuk indikator keberhasilan pengajaran dapat dilihat pada table 2 :

Pada table 2 bahwa nilai rata-rata skor total yang diperoleh peserta adalah 80,5 dengan skor total 100. Data di atas juga menunjukkan bahwa skor minimal yang diperoleh peserta adalah 
76,8

Berdasarkan hasil evaluasi, baik evaluasi proses maupun evaluasi hasil workshop menunjukkan hasil yang memuaskan. Guru SD sebagai mitra pengabdian cukup merasakan manfaatnya, Hal ini akan bermanfaat bagi mereka secara praktis dalam melaksanakan pembelajaran di kelas masing-masing

Tabel 1: Rekapitulasi evaluasi proses kegiatan

\begin{tabular}{lccccc}
\hline $\begin{array}{c}\text { Unsur yang } \\
\text { dinilai }\end{array}$ & $\begin{array}{c}\text { Buruk Sekali } \\
(\mathbf{\%})\end{array}$ & $\begin{array}{c}\text { Buruk } \\
(\mathbf{\%})\end{array}$ & $\begin{array}{c}\text { Cukup Baik } \\
(\mathbf{\%})\end{array}$ & $\begin{array}{c}\text { Baik } \\
(\mathbf{\%})\end{array}$ & $\begin{array}{c}\text { Baik Sekali } \\
(\%)\end{array}$ \\
\hline Materi & 0 & 0 & 24 & 40 & 36 \\
\hline Waktu & 0 & 0 & 24 & 36 & 40 \\
\hline Instruktur & 0 & 0 & 32 & 36 & 32 \\
\hline Fasilitas & 0 & 0 & 24 & 28 & 48 \\
\hline Kesesuaian & 0 & 0 & 24 & 36 & 40 \\
\hline
\end{tabular}

Tabel 2: Hasil Evaluasi Tugas Mandiri

\begin{tabular}{ll}
\hline Rata-rata & 80.5 \\
\hline Nilai Maksimum & 89,4 \\
\hline Nilai Minimum & 76,8 \\
\hline
\end{tabular}
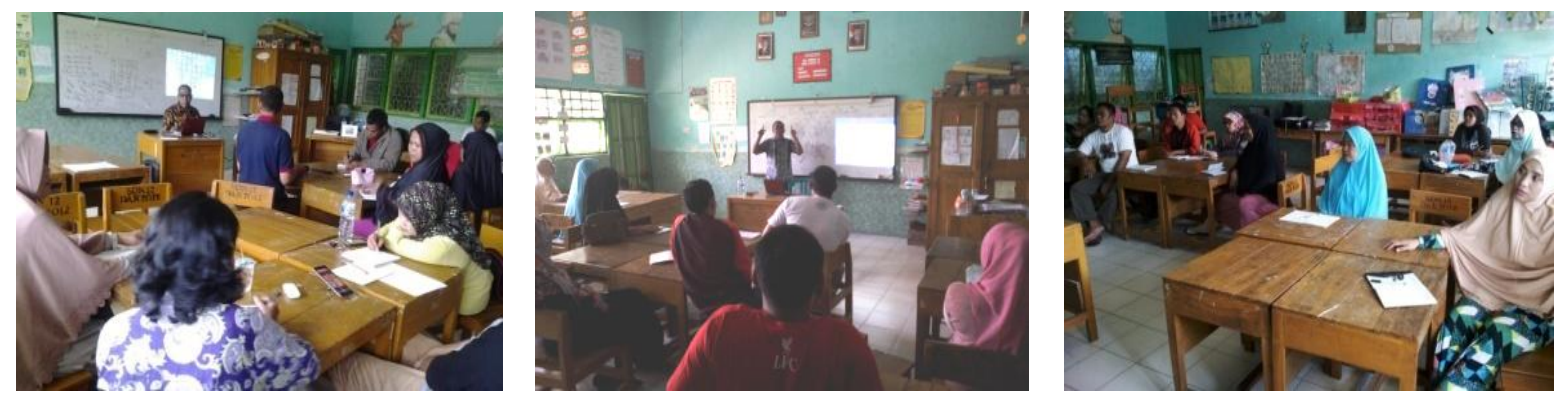

Gambar 1. Kegiatan pelaksanaan workshop

\section{KESIMPULAN \& SARAN}

Berdasarkan hasil evaluasi, baik evaluasi proses maupun evaluasi hasil workshop menunjukkan hasil yang memuaskan. Guru SD sebagai mitra pengabdian cukup merasakan manfaatnya. Hal ini akan bermanfaat bagi mereka secara praktis dalam melaksanakan pembelajaran di kelas masing-masing.

\section{DAFTAR PUSTAKA}

Departemen Pendidikan Nasional. 2017. Kurikulum 2013 Edisi Revisi. Jakarta : Depdiknas.

Subarinah, Sri. 2006. Inovasi Pembelajaran Matematika SD. Jakarta : Departemen Pendidikan Nasional Direktorat Jendral Pendidikan Tinggi.

Susanto, Ahmad. 2013. Teori Belajar Dan Pembalajaran Di Sekolah Dasar. Jakarta : Prenadamedia Group
Undang-undang Republik Indonesia Nomor 20 Tahun 2003 tentang Sistem Pendidikan Nasional. Jakarta : Sinar Grafika. 